\title{
New species of Curimatopsis from the río Caroni, Orinoco basin, Venezuela, with comments on $C$. macrolepis ə (Characiformes: Curimatidae)
}

Correspondence:

Bruno F. Melo brunfmelo@gmail.com

Submitted November 24, 2019

Accepted April 7, 2020

by Paulo Lucinda

Epub Jun 17, 2020

Online version ISSN 1982-0224

Print version ISSN 1679-6225

Neotrop. Ichthyol.

vol. 18, no. 2, Maringá 2020
${ }^{\circledR}$ Bruno F. Melo ${ }^{1}$

A new species of Curimatopsis is described from the highlands of the western Guiana Shield in the río Carapo and río Paragua, tributaries of the río Caroni in the Orinoco basin, southeastern Venezuela. The new species belongs to the Curimatopsis macrolepis clade due to its possession of a long lower jaw that projects past the anterior margin of the upper jaw, and separate first and second hypurals. The new species is diagnosed from remaining species of the Curimatopsis macrolepis clade by having a small-sized inconspicuous dark spot on the midlateral surface of the caudal peduncle, by details of body and fin pigmentation, and by additional morphometric characters. The distribution of C. macrolepis in the Amazon and Orinoco basins is updated based on the examination of museum specimens.

Keywords: Gran Sabana, Guiana Shield, Ostariophysi, Teleostei

Uma nova espécie de Curimatopsis é descrita da porção oeste do Escudo das Guianas dos ríos Carapo e Paragua, tributários do río Caroni, bacia do Orinoco no sudeste da Venezuela. A nova espécie pertence ao clado Curimatopsis macrolepis por possuir uma maxila inferior longa que se projeta além da margem anterior da maxila superior e primeiro e segundo hipurais separados. A nova espécie é diagnosticada das demais espécies do clado Curimatopsis macrolepis por possuir uma mácula escura pequena, inconspícua na superfície lateral do pedúnculo caudal, por detalhes de pigmentação do corpo e nadadeiras, e por dados morfométricos adicionais. A distribuição geográfica de C. macrolepis nas bacias do rio Amazonas e río Orinoco é atualizada baseada na análise de espécimes depositados em museus.

Palavras-chave: Gran Sabana, Escudo das Guianas, Ostariophysi, Teleostei

\footnotetext{
1 Laboratório de Biologia e Genética de Peixes, Departamento de Biologia Estrutural e Funcional, Instituto de Biociências, Universidade Estadual Paulista, IBB/UNESP, R. Prof. Dr. Antonio C. W. Zanin, 250, 18618-689 Botucatu, SP, Brazil. brunfmelo@gmail.com.
} 


\section{INTRODUCTION}

The 115 extant species of the Neotropical fish family Curimatidae (Fricke et al., 2020) are broadly distributed in all major river systems of South America, Panama and Costa Rica (Vari, 2003). Those species are currently assigned to eight genera: Curimatopsis Steindachner, 1876 (10 species), Curimata Bosc, 1817 (13 species), Potamorhina Cope, 1878 (five species), Psectrogaster Eigenmann, Eigenmann, 1889 (eight species), Pseudocurimata Fernández-Yépez, 1948 (six species), Curimatella Eigenmann, Eigenmann, 1889 (five species), Steindachnerina Fowler, 1906 (24 species), and Cyphocharax Fowler, 1906 (44 species). Fourteen new curimatid species have been described in the last 10 years (Fricke et al., 2020), five of them belonging to the genus Curimatopsis (Melo et al., 2016a; Melo, Oliveira, 2017; Dutra et al., 2018).

Curimatopsis is supported by 16 synapomorphies (Vari, 1982, 1989) and can be diagnosed by the distinctly rounded anterior margin of the maxilla, the absence of the laterosensory canal segment in the first infraorbital, and a reduced laterosensory system on the body, with pores restricted to only the anterior portion thereof (Vari, 1982,1989). Two main clades of Curimatopsis are well defined by morphological and molecular evidence: the C. macrolepis clade supported by three anatomical synapomorphies and the C. evelynae clade supported by five such synapomorphies (Vari, 1982, 1989; Melo et al., 2018). Five species are assigned to each clade distributed along lowlands of the Orinoco, Amazon, and Paraguay river basins, and coastal Atlantic rivers from the Guianas to northeastern Brazil (Vari, 1982; Melo, Oliveira, 2017; Dutra et al., 2018).

One species of each clade occurs in the Orinoco basin: Curimatopsis macrolepis (Steindachner, 1876), which is also distributed along the Amazon basin (type-locality: Tabatinga, rio Solimões), and C. evelynae Géry, 1964, which also occurs along the rio Negro downstream to Manaus (type locality: río Manacacías, río Meta) (Steindachner, 1876; Géry, 1964; Vari, 1982). At the time of the last revision (Vari, 1982), only a few records of both species were available in museum collections. Subsequent field collections showed that some species, such as C. macrolepis, have broader distributions than originally documented by Vari (1982). Here, a new species of Curimatopsis collected in tributaries of the río Caroni of the Orinoco basin is formally described and updated information on the distribution of C. macrolepis is provided based on examination of museum specimens.

\section{MATERIAL AND METHODS}

Counts and measurements follow Vari (1982) and Melo et al. (2016a). Measurements are point-to-point linear distances taken with digital calipers to a precision of $0.1 \mathrm{~mm}$. In the description, parentheses indicate the number of examined specimens for a particular count and an asterisk designates the value for the holotype. Radiographs (rd) were obtained for the holotype and 16 paratypes. Fused PU1+U1 is considered a single bone, and the vertebrae associated with the Weberian apparatus are counted as four elements. Curimatopsis microlepis Eigenmann, Eigenmann, 1889, was originally hypothesized as a member of the C. macrolepis clade (Vari, 1982), however, ongoing genetic studies by the author demonstrated that it does not belong to the clade; for this reason, the species was 
not included in the distribution map. Efforts to deposit type specimens in the country of origin were not successful. Institutional abbreviations are: American Museum of Natural History, New York (AMNH); Auburn University Museum of Natural History, Auburn (AUM); Colección Zoológica, Faculdad de Ciencias, Universidad del Tolima, Ibagué (CZUT-IC); Departamento de Zoologia e Botânica, Universidade Estadual Paulista, São José do Rio Preto (DZSJRP); Instituto Nacional de Pesquisas da Amazônia, Manaus (INPA); Laboratório de Biologia e Genética de Peixes, Universidade Estadual Paulista, Botucatu (LBP); Museum of Comparative Zoology, Harvard University, Cambridge (MCZ), Museu Paraense Emílio Goeldi, Belém (MPEG), and Museu de Zoologia da Universidade de São Paulo, São Paulo (MZUSP).

\section{RESULTS}

\section{Curimatopsis sabana, new species}

urn:Isid:zoobank.org:act:9CCFF945-1D49-4869-A869-86A943AB7C07

(Fig. 1, Tab. 1)

Holotype. AMNH 274996, 36.5 mm SL, rd, female, Venezuela, Bolívar, río Paragua, above second rapid upriver from the río Carapo mouth, río Caroni, Orinoco basin, approximately 5'35’35”N 6342'19”W, 26 Feb 1990, C. J. Ferraris \& A. MachadoAllison.

Paratypes. All from río Caroni, Orinoco basin, Bolívar, Venezuela. AMNH 91174, 7, females, rd, 29.4-43.1 mm SL, collected with holotype. AMNH 91175, 6, females, rd, 32.4-39.5 mm SL, río Carapo, near mouth, on right bank at sand beach, approximately 5 36’45”N 6341'28”W, 19 Feb 1990, A. Machado-Allison \& S. Ramirez. AMNH 91186, 2, females, 40.5-41.4 mm SL, río Paragua, at second rapid above río Carapo mouth, near right bank, approximately $5^{\circ} 35^{\prime} 33^{\prime} \mathrm{N} 63^{\circ} 42^{\prime} 18^{\prime \prime W}, 26$ Feb 1990, C. J. Ferraris et al. AUM 36458, 1, male, rd, 43.6 mm SL, río Paragua, drying pool, 10.3 km E of La Paragua, 6 50’21”N 63¹4’14”W, 8 Jun 2003, O. León, P. Pera \& N.K. Lujan. LBP 29208, 2, females, rd, 31.4-34.1 mm SL, collected with holotype.

Diagnosis. Curimatopsis sabana belongs to the C. macrolepis clade (C. jaci Melo, Oliveira, 2017, C. maculosa Melo, Vari, Oliveira, 2016, C. macrolepis, and C. melanura Dutra, Melo, Netto-Ferreira, 2018) and can be easily diagnosed from species of the $C$. evelynae clade (C. cryptica Vari, 1982, C. evelynae, C. guaporensis Melo, Oliveira, 2017, C. myersi Vari, 1982, and C. pallida Melo, Oliveira, 2017) by having a longer lower jaw that projects past the anterior margin of the upper jaw ( $v s$. lower jaw shorter and not overlapping the upper jaw), and by separate ( $v$ s. fused) first and second hypurals. Within the C. macrolepis clade, C. sabana is diagnosed from C. melanura by the absence ( $v s$. presence) of the dark pigmentation on the entire lower lobe of the caudal fin. It differs from $C$. jaci by the absence ( $v$ s. presence) of a distinctly reticulate color pattern on the flanks of females. It is diagnosed from C. maculosa by the possession of a round 


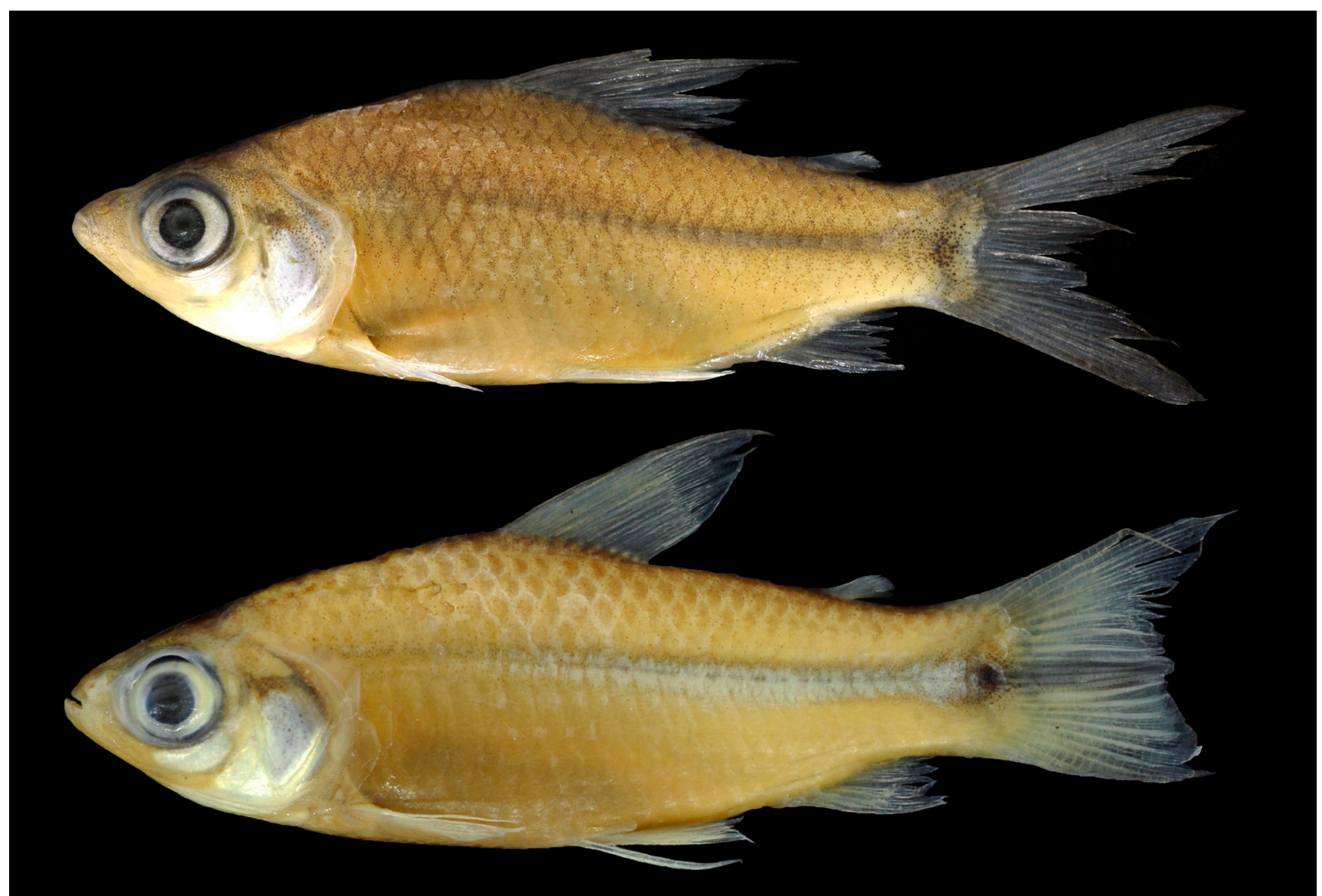

FIGURE 1 I Curimatopsis sabana, AMNH 274996, holotype, 36.5 mm SL, female, Venezuela, Bolívar, río Paragua, río Caroni, Orinoco basin (top). AUM 36458, paratype, 43.5 mm SL, male, Venezuela, Bolívar, río Paragua, río Caroni, Orinoco basin (bottom).

spot of black pigmentation, sometimes very faint, on the midlateral surface of the caudal peduncle ( $v$ s. a small posteriorly pointed spot overlapping the posterior midlateral scales), by the absence ( $v$ s. presence) of a gap of two or three scales separating the pigmentation of the midlateral stripe and the dark spot on caudal peduncle, by a deeper body, 34.1$39.9 \%$ of SL (vs. $26.0-31.6 \%$ of SL), and deeper caudal peduncle, $13.7-17.4 \%$ of SL (vs. $9.0-13.7 \%$ of SL). It differs from C. macrolepis by the possession of a circular and weakly pigmented spot on the caudal peduncle ( $v s$. horizontally elongated and strongly pigmented dark spot on caudal peduncle). Finally, it differs from C. microlepis by 26-28 (vs. 57-63) scales in the longitudinal series from the supracleithrum to the hypural joint.

Description. Morphometric data in Tab. 1. Body relatively short. Dorsal profile of head slightly convex from tip of snout to dorsal-fin origin; gradually descending and nearly straight from dorsal-fin origin to adipose-fin origin and then gently concave to origin of anterior dorsal caudal-fin procurrent ray. Ventral profile more or less evenly convex from chin to terminus of anal-fin base, then gently concave to origin of anterior ventral procurrent ray of caudal fin. Prepelvic region somewhat flattened transversely. Postpelvic region of body transversely rounded. 
TABLE 1 I Morphometric data for holotype and 18 paratypes of Curimatopsis sabana. Range includes holotype and all paratypes. $\mathrm{SD}=$ standard deviation.

\begin{tabular}{|r|c|c|c|c|}
\hline & Holotype & Mean & Range & SD \\
\hline Standard length (mm) & 36.5 & 36.0 & $29.4-43.5$ & - \\
\hline Percentages of standard length & & \\
\hline Greatest body depth & 37.4 & 36.4 & $34.1-39.9$ & 1.7 \\
\hline Snout to dorsal-fin origin & 53.1 & 53.7 & $50.0-57.2$ & 1.6 \\
\hline Snout to pectoral-fin origin & 36.1 & 36.2 & $33.8-38.8$ & 1.4 \\
\hline Snout to pelvic-fin origin & 61.6 & 60.5 & $57.7-63.6$ & 1.6 \\
\hline Snout to anal-fin origin & 85.5 & 82.8 & $78.4-85.5$ & 2.0 \\
\hline Dorsal-fin origin to hypural joint & 55.2 & 53.2 & $50.8-57.9$ & 1.8 \\
\hline Dorsal-fin origin to anal-fin origin & 45.9 & 44.3 & $40.9-46.6$ & 1.6 \\
\hline Dorsal-fin origin to pectoral-fin origin & 38.4 & 37.9 & $34.9-40.4$ & 1.5 \\
\hline Caudal-peduncle depth & 14.9 & 14.9 & $13.7-17.4$ & 0.8 \\
\hline Pectoral-fin length & 19.8 & 20.3 & $17.3-24.5$ & 1.7 \\
\hline Pelvic-fin length & 22.6 & 21.6 & $18.5-23.8$ & 1.2 \\
\hline Dorsal-fin length & 37.2 & 35.2 & $29.3-42.5$ & 2.8 \\
\hline Head length & 34.0 & 35.4 & $31.6-37.2$ & 1.4 \\
\hline Percentages of head length & & 2.3 \\
\hline Postorbital length & 44.0 & 45.0 & $40.6-48.5$ & 1.8 \\
\hline Interorbital width & 33.7 & 34.4 & $29.6-39.9$ & 2.4 \\
\hline
\end{tabular}

Head profile acutely triangular with bluntly pointed snout. Lower jaw longer than and projecting past the anterior to limit of upper jaw. Mouth subsuperior, horizontally aligned with center of orbit. Nostrils close; anterior nostrils circular to ovoid, posterior nostrils crescent-shaped with aperture not closed by thin flap of skin separating nares. Adipose eyelid slightly developed anterior to orbit.

Dorsal fin pointed, with distal margin straight and first and second branched rays longest. Distal margin of pectoral fin pointed. Tip of adpressed pectoral fin reaches three or four scales short of vertical through pelvic-fin origin. Pelvic fin profile slightly rounded. Tip of adpressed pelvic fin reaches two to four scales short of anal-fin origin. Caudal fin forked in females and middle caudal-fin rays elongated in males. Adipose fin present. Anal fin emarginate, anterior branched rays one-third length of ultimate ray. Tip of adpressed anal fin reaches two scales short of origin of ventral caudal-fin ray.

Lateral line longitudinal scales from supracleithrum to hypural joint $26(8), 27^{\star}$ (6) or 28 (5). Pored scales $4(3), 5^{\star}(5), 6(10)$, or 7 (1). Continuous series of scales posterior to hypural joint $3(1), 4^{\star}(17)$ or 5 (1). Scales in transverse series from dorsal-fin origin to pelvic-fin origin $11(11), 12^{\star}(7)$, or $13(1)$. Middorsal series of scales from tip of supraoccipital to dorsal-fin origin $9(5), 10$ (6), 11 (5), or $12^{\star}(2)$. Circumpeduncular scales $16^{\star}(19)$.

Dorsal-fin rays iii, $9^{\star}(19)$, first unbranched ray very short. Anal-fin rays iii, $7^{\star}(19)$, first ray very short. Pelvic-fin rays i, $8^{\star}(15)$, or i,9 (4). Pectoral-fin rays i,12 (2), i,13 ${ }^{\star}(6)$, i,14 (7), i,15 (3), or i,16 (1). Total vertebrae 27 (4), $28^{\star}(11)$, or 29 (2). 
Coloration in alcohol. Ground coloration tan to yellowish. Upper lip, snout, and dorsal portion of head and opercle with small, dark chromatophores; lower jaw with field of dark chromatophores, more so along margin of lower lip. Margins of scales along lateral, dorsolateral, and dorsal surface of body outlined by series of small dark chromatophores, but not forming a clear reticulate pattern; more diffuse pattern of small chromatophores on dorsal and dorsolateral regions of body. Dark pigmentation absent on scales over lateral surface and ventral region of the body. Thin-lying dusky stripe along midlateral surface of body from vertical through dorsal-fin origin to caudal peduncle. Dark concentration of chromatophores covering posterior midlateral scales and anterior portions of middle caudal-fin rays. Rays of dorsal, caudal, and anal fins distinctly outlined by small, dark chromatophores. Pectoral and pelvic fins with scattered, small, dark chromatophores. Adipose fin hyaline with small chromatophores concentrated on distal margin.

Sexual dimorphism. Only one male specimen (AUM 36458) was identified by its pronounced sexual dimorphism that is typical of species of Curimatopsis (Vari, 1982). The specimen has a deeper caudal peduncle (17.4\% of SL) than females (13.7-16.2\% of $\mathrm{SL}$ ), slightly elongate middle caudal-fin rays, and a clear enlargement of the penultimate principal ray of the caudal-fin lower lobe. These features are consistent with other species of Curimatopsis presenting sexual dimorphism (Vari, 1982; Melo, Oliveira, 2017).

Distribution. Curimatopsis sabana is only known from the Carapo and Paragua rivers, which are tributaries of the río Caroni, itself a right-bank tributary of the río Orinoco basin, in the western Guiana Shield in Venezuela (Fig. 2). Various specimens were collected in the region of the río Carapo, near Cerro Guaiquinima ( $4 \mathrm{~km}$ along the river, 300-310 $\mathrm{m}$ asl), and one specimen was collected in a drying pool of the lower río Paragua (272 m asl) (Fig. 3). The distribution suggests that C. sabana is restricted to higher elevations of the western Guiana Shield.

Etymology. The specific name sabana refers to the Gran Sabana, a major ecoregion in the western Guiana Shield of southeastern Venezuela, which encompasses the río Caroni basin. A noun in apposition.

Conservation status. Based on Armbruster, Taphorn (2013) who described Neblinichthys peniculatus from the río Carapo, the type locality of Curimatopsis sabana, the region is sparsely populated and difficult to access, which suggests a lack of significant threats for the species. In addition, another relatively recent expedition found one male specimen in the lower río Paragua, increasing the extent of the known occurrence for the species. Although the species lives in a relatively small area of occurrence, this factor alone does not qualify it for a threatened status. Given the available information, C. sabana is herein recommended to be categorized as Least Concern (LC) under the categories and criteria of the International Union for Conservation Nature (IUCN Standards and Petitions Subcommittee, 2019). 


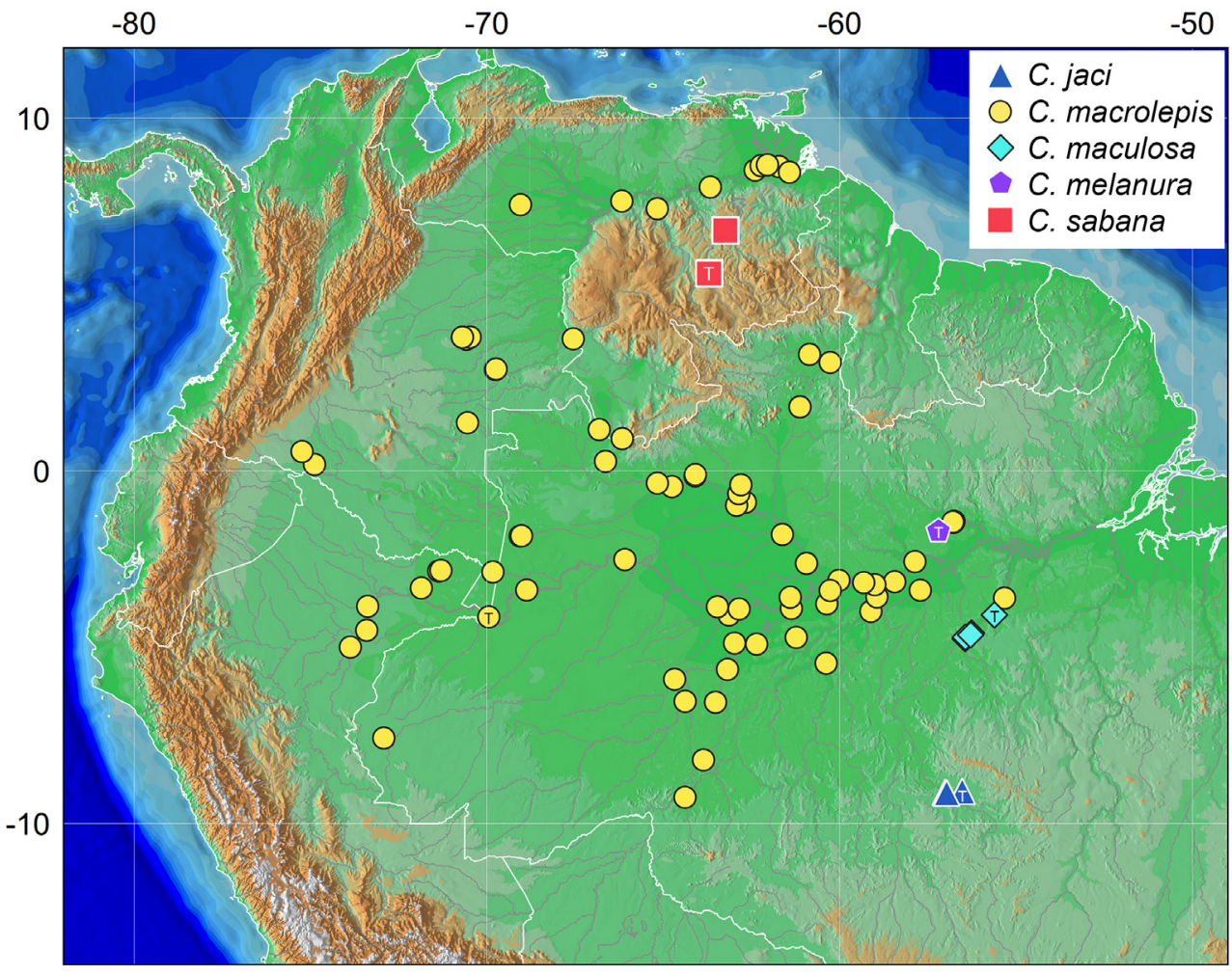

FIGURE 2 I Map of northern South America showing the collection localities of species of the Curimatopsis macrolepis clade in the Orinoco and Amazon basins. Note the distribution of C. sabana in highlands of the Guiana Shield. $\mathrm{T}$ = type locality.

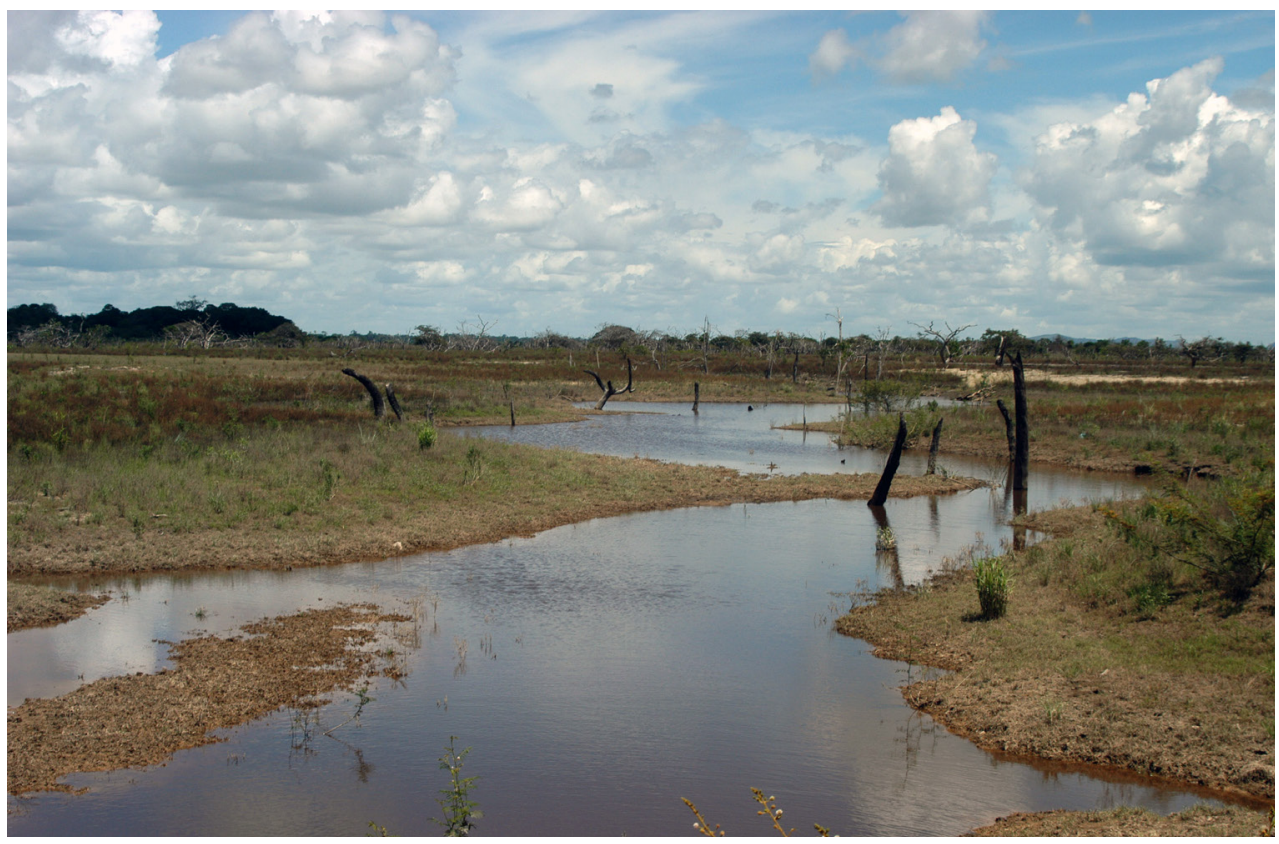

FIGURE 3 I Habitat of Curimatopsis sabana, AUM 36458, a drying pool of the río Paragua, tributary of the río Caroni. Photograph by J.W. Armbruster. 


\section{DISCUSSION}

Curimatopsis sabana is hypothesized to be a member of the C. macrolepis clade on the basis of one synapomorphy: the possession of an elongate lower jaw that projects past the anterior margin of the upper jaw (Vari, 1982, 1989). In addition, the species has the first and second hypurals separated, and the third hypural separated from the autogenous plate of the first and second hypurals. The alternative conditions with first and second hypurals fused and a connection of the third hypural with the autogenous plate represent synapomorphies of the C. evelynae clade (Vari, 1982: figs. 1-4, 1989). Relationships within the C. macrolepis clade are still unclear although a recent molecular study (Melo et al., 2016b) provided a hypothesis in which a cryptic species referred to C. macrolepis (rio Negro) represents the earliest split, followed by C. maculosa (rio Tapajós), and three other lineages of C. macrolepis corresponding to the Juruá, Madeira, and Nanay river basins, respectively. Ongoing research using genomic data also suggests that the distinctive C. microlepis, described from Jatuarana along the rio Amazonas below Manaus, does not belong to the C. macrolepis clade, and further research aim to redescribe and clarify the phylogenetic position of the species (Melo et al., unpublished).

Prior to this study, two species of Curimatopsis were known to occur in the Orinoco basin, one for each clade: C. evelynae, a very distinctive species of the C. evelynae clade, and C. macrolepis, described from Tabatinga, rio Solimões at the border of Brazil and Colombia (Steindachner, 1876). Vari (1982) examined five lots of C. macrolepis (AMNH 45092, USNM 226911, USNM 226975, USNM 226976, and USNM 226910) from the main río Orinoco, downriver of Caicara, in the Venezuelan states of Monagas and Delta Amacuro (Vari, 1982: fig. 12). Those specimens along with others from the Orinoco examined here, possess a densely pigmented, horizontally elongate spot on the caudal peduncle, a unique pattern within the C. macrolepis clade (Vari, 1982), and clearly distinct from that of C. sabana (Fig. 4). In fact, no other species in the clade possess such a densely pigmented spot on the caudal peduncle (Melo et al., 2016a; Melo, Oliveira, 2017; Dutra et al., 2018) suggesting that such pattern can be used as a diagnostic feature of C. macrolepis stricto sensu.

The distribution of Curimatopsis macrolepis is herein updated (see Fig. 2 and Material examined). In the Amazon basin, the species is distributed along the rio Solimões/ Amazonas, and the tributaries Aripuanã, Branco, Japurá, Juruá (cryptic), Madeira (cryptic), Nanay, Negro (cryptic), Purus, Putumayo, Solimões, Takutu, Tapajós, Trombetas, Uatumã, Ucayali, Uiraricoera, and Vaupés rivers. It is noteworthy that populations of C. macrolepis from the Juruá, Madeira, and Negro river basins represent cryptic species (Melo et al., 2016b). In the Orinoco basin, C. macrolepis occurs in the main channel of the río Orinoco and the tributaries Apure, Atabapo, Caura, Delta Amacuro, and Orocopiche rivers. While C. macrolepis is commonly found in lowland portions of those basins, C. sabana is allopatrically endemic to the highlands of the Guiana Shield (>270 $\mathrm{m}$ asl) in the Carapo and Paragua rivers, río Caroni basin (Fig. 2).

The río Caroni drains into the Gran Sabana of eastern Venezuela and its headwaters come from the highlands of tepuis on the borders of Brazil, Guyana and Venezuela (Lasso et al., 1989). Several fish species are endemic to the río Caroni, for example Brycon coquenani Steindahner, 1915, Lebiasina uruyensis Fernández-Yépez, 1967, 

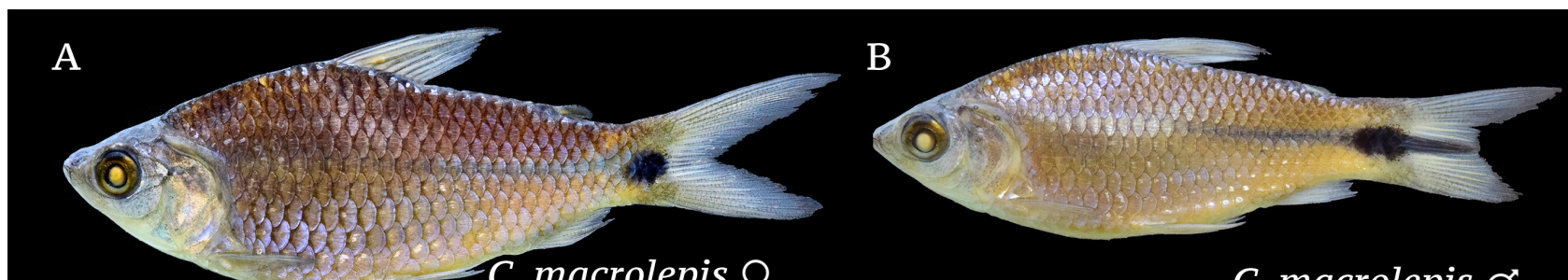

C. macrolepis $\mathrm{O}^{\prime}$
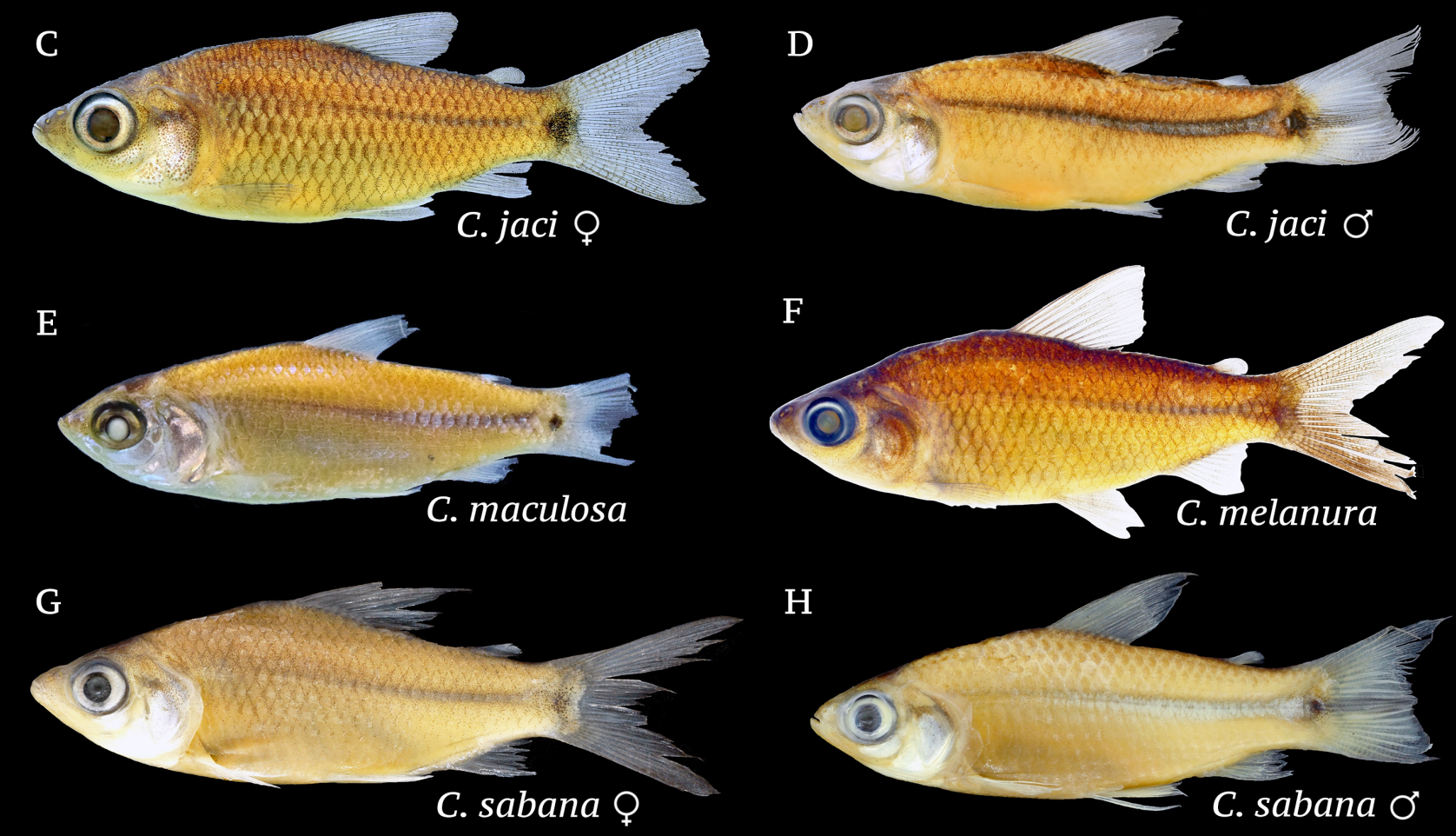

FIGURE 4 I Species of the Curimatopsis macrolepis clade: A-B) C. macrolepis, LBP 22425, rio Solimões, Letícia, Colombia; C) C. jaci, female, MZUSP 121197, holotype, rio Cristalino, upper Tapajós basin; D) C. jaci, male, MZUSP 116668, paratype, rio São Benedito, upper Tapajós basin; E) C. maculosa, LBP 13907, paratype, middle rio Tapajós; F) C. melanura, MPEG 15335, holotype, rio Nhamundá; G) C. sabana, female, AMNH 274996, holotype, río Caroni basin; H) C. sabana, male, AUM 36458, paratype, río Caroni basin. Photos by Bruno Melo (A-E, G-H) and Guilherme Dutra (F).

and Neblinichthys peniculatus Armbruster, Taphorn, 2013 (Fernández-Yépez, 1967; Armbruster, Taphorn, 2013; Lima, 2017). Interestingly, Armbruster, Taphorn (2013) described N. peniculatus based on the material collected by Carl Ferraris, Antonio Machado-Allison, and colleagues in 1990 in the río Carapo, which also yelded the specimens of Curimatopsis sabana described here. Those authors pointed out that the río Carapo is located in a remote region near tepui Cerro Guaiquinima above Salto Uraima, a large waterfall of the río Paragua (Armbruster, Taphorn, 2013). Curimatopsis sabana appeared at first to be another endemic to that remote region, but a single paratype extends the distribution of the species to the río Paragua in the Caroni basin. 
Comparative material examined. Curimatopsis cryptica: Guyana: USNM 226872, holotype, $26.9 \mathrm{~mm} \mathrm{SL}$, AMNH 45094, 1, $40.0 \mathrm{~mm} \mathrm{SL}$, AMNH 45095, paratypes, 2, 27.6-28.9 mm SL. Brazil: AMNH 45096, 1, 33.3 mm SL, USNM 226880, 11, 21.2-27.6 mm SL, MZUSP 15974, 2, 26.2-29.6 mm SL, MZUSP 15976, paratypes, 2, 34.5-34.6 mm SL. Curimatopsis evelynae: Colombia: USNM 198644, holotype, 22.3 mm SL, USNM 198638, 1, 27.6 mm SL, AMNH 43099, paratypes, 54, 30.7-33.0 mm SL. Curimatopsis guaporensis: Brazil: MZUSP 121189, holotype, $24.0 \mathrm{~mm}$ SL, DZSJRP 19418, 9, 20.3-25.7 mm SL, LBP 22725, paratypes, 4, 19.9-24.7 mm SL. Curimatopsis jaci: Brazil: MZUSP 121197, holotype, $28.1 \mathrm{~mm}$ SL, LBP 22726, 1, paratype, $31.2 \mathrm{~mm}$ SL, MZUSP 118861, paratypes, 4, 28.3-31.3 mm SL. Curimatopsis macrolepis: Venezuela: AMNH 45092, 1, 29.2 mm SL, AMNH 74564, 6, 48.6-61.7 mm SL, AMNH 74565, 6, 32.4-38.2 mm SL, MZUSP 77811, 2, USNM 226910, 1, 31.9 mm SL, USNM 226911, 2, 28.0-28.3 mm SL, USNM 226975, 3, 30.9-34.1 mm SL, USNM 226976, 10, 22.7-41.9 mm SL, USNM 235467, 1, 29.7 mm SL, USNM 235475, 1, 25.4 mm SL, USNM 258086, 2, 27.4-27.8 mm SL, USNM 295587, 5, 33.2-35.8 mm SL. Colombia: AMNH 32946, 6, 37.1-47.8 mm SL, CZUT-IC 4507, 3, CZUT-IC 4850, 4, CZUT-IC 9019, 4, CZUT-IC 10873, 5, CZUT-IC 14172, 1, CZUT-IC 14113, 2, CZUT-IC 14679, 30, CZUT-IC 14390, 1, CZUT-IC 14759, 1, LBP 22425, 11, Leticia. Peru: AMNH 45088, 2, 30.2-38.9 mm SL, AMNH 45089, 3, 32.5-33.4 mm SL, AMNH 45090, 1, 51.9 mm SL, AMNH 45093, 1, $41.7 \mathrm{~mm}$ SL, AMNH 78116, 6, 23.4-27.2 mm SL, LBP 12426, 6, 32.1-33.2 mm SL. Brazil: AMNH 45091, 1, $45.8 \mathrm{~mm}$ SL, AMNH 221368, 7, 25.7-33.1 mm SL, LBP 4087, 25, 30.0-37.4 mm SL, LBP 4489, 11, 22.8-46.5 mm SL, LBP 7038, 6, LBP 12064, 3, 24.1-30.9 mm SL, LBP 19768, 2, INPA 4801, 5, INPA 4802, 2, INPA 9786, 1, INPA 16532, 10, INPA 17438, 1, INPA 24489, 36, INPA 26610, 11, INPA 28698, 3 , INPA 29242, 1, INPA 30666, 3, INPA 33206, 38, INPA 33299, 8, INPA 33233, 3 , INPA 33248, 12, INPA 33301, 2, INPA 33375, 1, INPA 34916, 1, INPA 35083, 7, INPA 35314, 1, INPA 35435, 1, INPA 36393, 71, INPA 37139, 4, INPA 39071, 12, INPA 39210, 3, INPA 39350, INPA 39637, 2, INPA 41467, 5, INPA 41987, 2, INPA 42103, 1, INPA 42743, 1, INPA 44216, 4, INPA 46843, 1, INPA 48316, 6, INPA 49156, 3, INPA 49349, 2, INPA 50050, 13, INPA 50071, 13, INPA 50170, 23, INPA 50471, 1, INPA 51200, 14, INPA 51319, 5, rio Daraá. INPA 51491, 6, INPA 51713, 4, INPA 51750, 12, INPA 51978, 1, INPA 52630, 14, INPA 52712, 177. Curimatopsis maculosa: Brazil: MZUSP 118659, holotype, 24.6 mm SL, MZUSP 22038, 9, 24.127.8 mm SL, MZUSP 25412, paratypes, 23, 18.0-26.3 mm SL. Curimatopsis melanura: Brazil: MPEG 15335, holotype, 41.0 mm SL, MPEG 35300, paratypes, 4, 34.1-38.2 mm SL, LBP 19556, 1, paratype, 37.9 mm SL. Curimatopsis microlepis: Brazil: MCZ 20344, holotype, $83.7 \mathrm{~mm}$ SL, INPA 37441, 1, $58.1 \mathrm{~mm}$ SL, INPA 41825, 1, $75.7 \mathrm{~mm}$ SL. Curimatopsis myersi: Paraguay: USNM 233602, holotype, 37.4 mm SL, USNM 233601, paratypes, 6, 31.6-38.7 mm SL, MZUSP 20659, 1, paratype, $36.6 \mathrm{~mm}$ SL. Curimatopsis pallida: Brazil: MZUSP 121192, holotype, 36.7 mm SL, MZUSP 95267, paratypes, 4, 33.1-36.8 mm SL. 


\section{ACKNOWLEDGMENTS}

Thanks to Melanie Stiassny, Scott Schaefer, Barbara Brown, Thomas Vigliotta (AMNH), Lynne Parenti, Jeffrey Clayton, Sandra Raredon, Diane Pitassy, Kris Murphy (USNM), Jonathan Armbruster, David Werneke (AUM), George Lauder and Andrew Williston (MCZ) for curatorial assistance, and to Kimberly Bernotas (AMNH) for assistance with radiographs. Thanks also to Jonathan Armbruster (AUM) and Nathan Lujan (AMNH) for the photograph of the habitat in Fig. 3, and to Kristen Olson (AMNH) for kindly improving early versions of the manuscript. Thanks to Donald Taphorn, Mark Sabaj, and Brian Sidlauskas for improving the paper. This paper was entirely developed during a sabbatical period at the AMNH granted by FAPESP 18/24040-5 and received additional support from FAPESP grants 14/265083 and 16/11313-8, and by the CNPq Universal grant 140193/2015-4.

\section{REFERENCES}

- Armbruster JW, Taphorn DC. Description of Neblinichthys peniculatus, a new species of loricariid catfish from the río Paragua drainage of Venezuela. Neotrop Ichthyol. 2013; 11(1):65-72. http://dx.doi.org/10.1590/ S1679-62252013000100007

- Dutra GM, Melo BF, Netto-Ferreira AL. A new species of Curimatopsis Steindachner (Characiformes: Curimatidae) from the Rio Nhamundá, Amazon basin. J Fish Biol. 2018; 92(2):515-22. https://doi.org/10.1111/jfb.13540

- Fernández-Yépez A. Primera contribución al conocimiento de los peces, con descripción de dos especies y una subespecie nuevas. Resultados zoológicos de la expedición de la Universidad Central de Venezuela. Acta Biol Venez. 1967; 5:159-77.

- Fricke R, Eschmeyer WN, Fong JD. Eschmeyer's Catalog Fishes: Species by family/subfamily [Internet]. San Francisco: California Academy of Science; 2020. Available from: http://researcharchive. calacademy.org/research/ichthyology/ catalog/SpeciesByFamily.asp

- Géry J. Preliminary description of seven new species and two new genera of characoid fishes from the Upper rio Meta in Colombia. TFH. 1964; 13(4):41-48.

- International Union for Conservation of Nature (IUCN). Standards and Petitions Subcommittee. Guidelines for using the IUCN Red List categories and criteria, Version 14 [Internet], Cambridge, 2019. Available from: https://www.iucnredlist. org/resources/redlistguidelines
- Lasso CA, Machado-Allison A, Hernández RP. Consideraciones zoogeográficas de los peces de La Gran Sabana (Alto Caroní) Venezuela, y sus relaciones con las cuencas vecinas. Mem Soc Cienc Nat La Salle. 1989; 49-50(131134):109-29.

- Lima FCT. A revision of the cis-andean species of the genus Brycon Müller \& Troschel (Characiformes: Characidae). Zootaxa. 2017; 4222(1):1-189. http://dx.doi. org/10.11646/zootaxa.4222.1.1

- Melo BF, Ochoa LE, Vari RP, Oliveira C. Cryptic species in the Neotropical fish genus Curimatopsis (Teleostei, Characiformes). Zool Scr. 2016b; 45(6):65058. https://doi.org/10.1111/zsc.12178

- Melo BF, Oliveira C. Three new species of Curimatopsis (Characiformes: Curimatidae) from the Amazon basin. J Fish Biol. 2017; 91(2):528-44. https://doi.org/10.1111/ jfb.13360

- Melo BF, Sidlauskas BL, Hoekzema $\mathrm{K}$, Vari RP, Dillman CB, Oliveira C. Molecular phylogenetics of Neotropical detritivorous fishes of the family Curimatidae (Teleostei: Characiformes). Mol Phylogenet Evol. 2018; 127:800-12. https://doi.org/10.1016/j.ympev.2018.06.027

- Melo BF, Vari RP, Oliveira C. Curimatopsis maculosa, a new species from the Rio Tapajós, Amazon basin, Brazil (Teleostei: Curimatidae). Ichthyol Explor Freshw. 2016a; 27(4):303-08. 
- Steindachner F. Ichthyologische Beiträge (V.), II: Über einige neue Fischarten, insbesondere Characinen und Siluroiden aus dem Amazonenstrome. Sitzungsberichte der kaiserliche Akademie der Wissenschaften. 1876; 74:73-167. Available from: https://www. biodiversitylibrary.org/item/35546

- Vari RP. Systematics of the Neotropical characoid genus Curimatopsis (Pisces: Characoidei). Smithson Contrib Zool. 1982; 373:1-28. https://doi.org/10.5479/ si.00810282.373
- Vari RP. A phylogenetic study of the Neotropical characiform family Curimatidae (Pisces: Ostariophysi). Smithson Contrib Zool. 1989; 471:1-71. https://doi.org/10.5479/si.00810282.471

- Vari RP. Family Curimatidae. In: Reis RE, Kullander SO, Ferraris CJ, editors. Check list of the freshwater fishes of South and Central America. Porto Alegre: Edipucrs; 2003. p.51-64.

\section{Neotropical |chthyology}

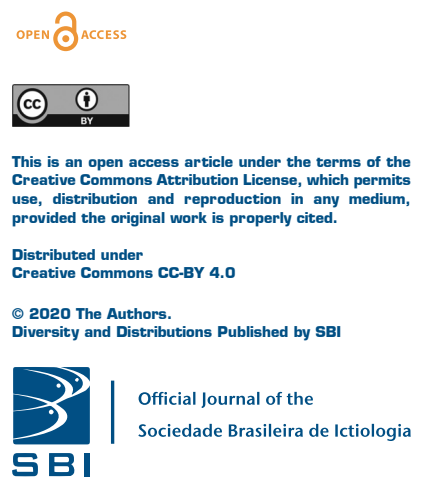

\section{AUTHOR'S CONTRIBUTION}

Bruno F. Melo: Conceptualization, Data curation, Funding acquisition, Formal analysis, Investigation, Methodology, Resources, Writing-original draft, Writing-review \& editing.

\section{ETHICAL STATEMENT}

Not applicable.

\section{COMPETING INTERESTS}

The author declares no competing interests.

\section{HOW TO CITE THIS ARTICLE}

- Melo BF. New species of Curimatopsis from the río Caroni, Orinoco basin, Venezuela, with comments on C. macrolepis (Characiformes: Curimatidae). Neotrop Ichthyol. 2020; 18(2):e200002. https://doi.org/10.1590/1982-0224-2020-0002 